\title{
AN EMPIRICAL STUDY ON THE EFFECT OF ECO-TOURISM VISITORS' ENVIRONMENTAL ATTITUDES ON ENVIRONMENTAL BEHAVIOR
}

\author{
LI, L. - WANG, L. Y.* \\ School of Humanities and Economic Management \\ China University of Geosciences, Beijing \\ (e-mail: Lilin@cugb.edu.cn; tel: + 86-10-82323059) \\ *Corresponding author \\ e-mail: lywang@cugb.edu.cn; tel: + 86-10-82322490 \\ (Received $19^{\text {th }}$ Sep 2016; accepted $15^{\text {th }}$ Nov 2016)
}

\begin{abstract}
Eco-tourism, a tourism business emerged in the end of $20^{\text {th }}$ century, covers the education awareness of environmental conservation. Without quality environment, visitors would not actively go sightseeing. For this reason, sightseeing, to some degree, is attached to the environment. Domestic and international public sectors and private sectors therefore discuss eco-tourism related issues, think of reducing the impact of eco-tourism on the environment, and maintain the right to enjoy natural resources and the environment for descendants. Visitors to Yongchun Niumulin Ecological Tourism Zone, the research object in this study, are distributed and collected the questionnaire on-site. Total 360 copies of the questionnaire are distributed, and 251 valid copies are retrieved, with the retrieval rate $70 \%$. The research results are summarized as following. 1. Environmental attitudes present significant correlations with tourist satisfaction. 2. Tourist satisfaction shows remarkable correlations with environmental behavior. 3 . Environmental attitudes reveal notable correlations with environmental behavior. The suggestion, proposed according to the research result in this study, expects to reduce the impact of eco-tourism on the environment and maintain the rights to enjoy natural resources and the environment for descendants.
\end{abstract}

Keywords: persuasive action, environmental ethics, ecological management, characteristics, satisfaction

\section{Introduction}

In past years, changes of economic patterns, living habits, two-day weekend, and the increase in national income in Taiwan have the people stress on sightseeing and recreation activity after satisfying the material life. The expense on sightseeing and recreation activity is also increased to satisfy the spiritual and psychological life. Moreover, active promotion of domestic travel by the government, convenient transportation, and the promotion and introduction of mass media have recreation become an essential part of life. With narrow land and dense population, crowded and busy urban life and inadequate recreation space and facilities in Taiwan have the public desire to return to the countryside and be close to the nature. Because of the popularity of environmental awareness, the advance of conservation zone management and the change in consumer markets, a travel pattern different from traditional mass tourism but combining recreation activity with ecological conservation, environmental education, and cultural experience, are generated, called eco-tourism. Sightseeing activity is called "an industry without chimney" as it is regarded as an industry without pollution. The environment is the basis of sightseeing; without quality environment, few visitors would actively go sightseeing. In this case, sightseeing, to some extent, is attached to the 
environment. Eco-tourism awareness is rising in past years. Being a tourism business emerged in the end of $20^{\text {th }}$ century, eco-tourism results in threats to the environment in the next century. Eco-tourism related issues are therefore discussed domestically and internationally, thinking of reducing the impact of eco-tourism on the environment and maintaining the right to enjoy natural resources and the environment for descendants.

\section{Literature and hypothesis}

\section{Environmental attitudes}

Maulidya et al. (2014) pointed out attitudes as a persistent and consistent tendency towards people, affairs, and the surrounding world. Hanington and Martin (2012) regarded attitudes as an inner psychological idea acquired through oral reports and behavior observation; and, attitudes was specified through individual introspection. As a matter of fact, attitudes stand for the persistent emotion and belief learned by certain objects, and such emotion and belief have people who have such attitudes present specific behavior towards such objects, relating to understanding, evaluating, and predicting individual behavior. In other words, attitudes are individual positive or negative evaluation towards certain behaviors, relating to belief. Satyanarayana et al. (2012) regarded the environment as whatever could stimulate, affect, or induce individual and group behavior, referring to visitors' travel destinations as the object formed by eco-tourism environmental attitudes. It presented the relative relationship between a subject (visitors) and an object (the environment). In this case, environmental attitudes could be defined as the belief composition of special situations in the environment, the entire environment or the people or objects directly related to the environment. Such composition contained the overall evaluation of for or against and preference or aversion. The "environmental attitudes towards eco-tourism" is defined as visitors' attitudes towards the travel environment, including cognition, emotion, and intention.

Husted et al. (2014) indicated that environmental attitudes should focus on environmental ethics, including natural resources, environment development, environment protection, ecological relationship, and environmental responsibility. Furthermore, the structure of New Environment Paradigm (NEP) was to challenge the idea of protecting the environment with tradition and covered three new norms of (1) believing in human ability to destroy the environment, (2) restricted growth, and (3) proper rules to restrict human behavior in the nature (Cheung et al., 2014). Such a theory also conforms to the spirit of eco-tourism. Referring to Hsiao and Ou (1998), environmental attitudes towards eco-tourism in this study combine the idea of NEP and the definition of eco-tourism to deduce the dimensions of environmental ethics, environmental education, and environmental resources.

(1) Environmental ethics: Environmental ethics of eco-tourism explains the moral subject of "ecology centered" that it does not simply cherish and respect natural resources, but considers, under the entire natural value and responsibility, to think based on ecology, to combine science and ethics, and to promote the concern to biomass, and even non-biomass, including human beings, animals and plants, rivers, and natural landscape. Such a spirit is the basic respect and concern about the nature as well as the ignorable attitudes towards the environment in tourism. 
(2) Environmental education: Environmental education aims to cultivate environment responsible citizens who present perception and sensitivity on the environment and environment related issues and show basic knowledge of the environment and the problem. Environmental education therefore would be a major content of eco-tourism, allowing visitors to have different experiences in eco-tourism and powerfully persuading visitors to participate in environment conservation (Zsóka et al., 2013).

(3) Environmental resources: "Sustainable development" is the guideline in eco-tourism. In addition to satisfying visitors' self-satisfaction and sense of experience in the travel, it also avoids the unrecovered impact of travel on the environment. As a result, sustainable development, based on stable ecological systems, stresses on biodiversity, develops the quality satisfying human life, and establishes the balance between "demand" and "restriction" for the environment and resources.

\section{Tourist satisfaction}

Chiu et al. (2014) stated that "satisfaction", as a useful measuring indicator, used to be used for measuring people's opinions about products, work, quality of life, communities, or outdoor recreation quality. However, customer satisfaction still requires diverse discussions as everyone has distinct personal traits and socio-economic background and appears diverse attitudes, preference, and motivation about the same object. Nunkoo and Ramkissoon (2011) considered that customer satisfaction, as the emotional or cognitive judgment according to the background at the time, was positively affected by emotion and cognition. Ahmed et al. (2015) measured and evaluated customer satisfaction with retail stores and proposed that satisfaction was the service quality being different from the satisfaction level in the product acquisition or consumption process; service quality was customers' continuous evaluation of affairs, while satisfaction level was the temporary emotional reaction towards affairs. Senyolo et al. (2014) also thought that consumer satisfaction could be regarded as an overall evaluation reaction, which stood for consumers' subjective reaction to products with different attributes. Jung et al. (2015) pointed out consumer satisfaction as the overall perception, which could be directly evaluated, of like after the consumption. Buckley et al. (2012) regarded customer satisfaction as individual satisfaction from the comparison of product performance cognition and personal product expectation. Satisfaction level was the difference function between perceived performance and expectation. Teksoz et al. (2012) indicated that consumers would express personal feelings about the use of products with emotional words and generate the emotions of satisfaction or dissatisfaction. Regarding the rational cognition evaluation, Kang et al. (2012) studied consumer behavior and proposed that satisfaction was the cognition of consumers purchasing certain products by judging the acquired reward and compensation being proper for the sacrifice.

Referring to Planning and Management of Sightseeing and Recreation Areas written by Kang et al. (2012), 1.characteristics, including uniqueness, appreciation, originality, experience, and history and 2.development potential, containing served population, accessibility, quality, and management are the evaluation standards of tourist satisfaction in eco-tourism. 


\section{Environmental behavior}

Environmental behavior studies "the interaction between humans and the environment" (Chaminuka et al., 2012). De Gusmão Pedrini et al. (2015) proposed the broad and narrow explanation of behavior in psychology. Narrow behaviors referred to individual "explicit motions", such as walking, working, and running. Such motions could be directly observed by others' senses or recorded by videos and cameras; and, the analyzed and processed "activity" was behavior. In addition to explicit motions, broad behavior was defined as inner psychology, like motivation, thinking, awareness, belief, and value, which were the drive of explicit behavior and presented the possibility and tendency to determine the behavior. Bauer (2012) pointed out the necessity of citizens, after having knowledge, attitudes, and skills, taking actions to participate in solving various environmental problems. Such behavioral intention or results should be compatible with the natural ecological process. In the discussion of visitor reaction towards the environment, Lemes et al. (2014) included behavior in explicit motions to avoid visitors' psychological factors in the complicated relationship between attitudes and behavior.

Referring to Lo and Jim (2015), the dimensions of environmental behavior contain the following.

1. Persuasive action, referring to force people taking positive environmental behavior with speech. Persuasion could change people's belief or value, such as discussion, debate, speech, comment in newspaper and magazine, and guided education activity.

2. Consumption action, referring to the economic threats or action taken by individuals or groups to change certain commercial or industrial behavior, such as refusing to buy products with impact on the environment, processed food, or food packed with too much plastic.

3. Ecological management, referring to actual action taken by individuals or groups to maintain or enhance current ecological systems, such as reforestation, recycle, and conservation of energy.

4. Legal action, referring to individuals, groups, or organizations taking legal action, aiming at reinforcing or modifying environment regulations or banning certain behavior, to solve environmental problems, such as accusation, warning, and court injunction.

\section{Research hypothesis}

When studying environmental behavior, researchers discovered several factors in environmental behavior. Besides, literatures indicated that the correlation between specific environmental attitudes and behavior was more important than general attitudes as specific attitudes could predict relevant environmental behavior (Damodaran, 2014). Knowledge, attitudes, and responsible environmental behavior showed positive correlations, revealing that people with more knowledge or active attitudes would better engage in responsible environmental behavior (Ke, 2012). Besides, an individual with responsibility for the environment or oral commitment to the environment would be more willing to precede environmental behavior (Shen, 2013). Researchers discussed the relationship between environmental behavior and various factors and discovered that ones with positive environmental attitudes would not necessarily practice conservation behavior actively (Ramdas and Mohamed, 2014). Nevertheless, researchers discovered, 
in the research on factors in responsible environmental behavior, that individuals with more positive attitudes towards environmental issues would present higher responsible environmental behavior (Cheung et al., 2014). With New Environment Paradigm Scale and Responsible Environmental Behavior Scale, researchers measured the environmental concept and the intention to take responsible environmental behavior of the freshmen in normal universities and discussed the relationship between the two. It was found that the freshmen in normal universities with higher support of New Environment Paradigm Scale would have higher intention to take responsible environmental behavior (Zhou et al., 2013). The following hypothesis is therefore established in this study.

H1: Environmental attitudes present significant correlations with tourist satisfaction.

Researchers indicated that visitors would induce positive emotion after experiencing eco-tourism, and the satisfaction and environmental behavior would appear positive effects (Reimer and Walter, 2013). In the research on visitors to Yangmingshan National Park, Shrode (2012) pointed out the positive correlation between tourist satisfaction and environmental behavior, and visitors with higher tourist satisfaction presented higher environmental behavior. Ly and Bauer (2014) indicated that visitors with higher tourist satisfaction showed higher responsible environmental behavior. A study on Penghu, Taiwan, also proposed that tourists with higher satisfaction showed higher environmental behavior, with positive correlations (Wu, 2012). However, it is considered in this study that users with high satisfaction would have the idea of "love me, love my dog" so that they could perform positive environmental behavior. The following hypothesis is therefore established in this study.

$\mathrm{H} 2$ : Tourist satisfaction shows remarkable correlations with environmental behavior.

Samdin et al. (2013) discovered that consumers highly concerning about the environment appeared higher support of eco-tourism, intention to choose eco-tourism, and satisfaction. Lu and Stepchenkova (2012) stated that visitors' attitudes towards eco-tourism could predict the behavior during or after the travel; visitors with more positive environmental attitudes and better agreement with the environment management strategy were more easily sensitive to environmental issues and willing to participate in relevant conservation action. Visitors with incorrect attitudes and concepts about environmental resources, on the other hand, did not respect the environment and were not willing to conform to the regulations or appeared low satisfaction. Consumers with stronger motivation of eco-tourism would reinforce the relationship between eco-tourism information and attitudes. Consumers with strong environmental attitudes would collect eco-tourism information, or those with good perception might show stronger satisfaction. The following hypothesis is further established in this study.

H3: Environmental attitudes reveal notable correlations with environmental behavior.

\section{Method and research object}

\section{Research object}

Visitors to Yongchun Niumulin Ecological Tourism Zone, as the research object, are distributed and collected the questionnaire on-site. A total of 360 copies of the 
questionnaire are distributed and 251 valid copies are collected, with the retrieval rate 70\%. Yongchun Niumulin Ecological Tourism Zone, with the good name of "Minnan Xishuangbanna", has the original forest groups which are best conserved in southern Fujian areas and show the best characteristics. Located in Xiayang Township, Yongchun County, Quanzhou City, it is a national AAAA level tourist attraction and provincial natural reserve as well as the ecological education base and science education base in Fujian Province.

\section{Analysis method}

Regression Analysis is applied to understand the relationship among environmental attitudes, tourist satisfaction, and environmental behavior.

\section{Analysis result}

\section{Reliability and validity analysis}

With Factor Analysis, environmental attitudes in this study is extracted three factors of "environmental ethics" (eigenvalue $=3.762, \alpha=0.83$ ), "environmental education" (eigenvalue $=2.831, \alpha=0.86$ ), and "environmental resources" (eigenvalue=2.475, $\alpha=0.81$ ). The accumulated covariance explained achieves $83.762 \%$.

Tourist satisfaction, with Factor Analysis, is extracted two factors of "characteristics" (eigenvalue $=2.538, \alpha=0.88$ ) and "development potential" (eigenvalue $=1.633, \alpha=0.80$ ). The accumulated covariance explained reaches $80.755 \%$.

Environmental behavior, with Factor Analysis, is extracted four factors of "persuasive action" (eigenvalue $=3.946, \quad \alpha=0.89$ ), "consumption action" (eigenvalue $=3.325, \alpha=0.90$ ), "ecological management" (eigenvalue $=2.862, \alpha=0.84$ ), and "legal action" (eigenvalue $=2.571, \alpha=0.82$ ). The accumulated covariance explained achieves $79.276 \%$.

\section{Correlation Analysis of environmental attitudes and tourist satisfaction}

To test H1, the analysis result, Table 1, shows significant effects of environmental ethics $\left(\mathrm{t}=2.215^{* *}\right)$, environmental education $\left(\mathrm{t}=2.436^{* *}\right)$, and environmental resources $\left(\mathrm{t}=2.388^{* *}\right)$ on characteristics and remarkable effects of environmental ethics $(\mathrm{t}=2.162 * *)$, environmental education $(\mathrm{t}=1.934 *)$, and environmental resources $\left(\mathrm{t}=2.457^{* * *}\right)$ on development potential that $\mathrm{H} 1$ is supported.

Table 1. Analysis of factors in environmental attitudes and tourist satisfaction

\begin{tabular}{|c|c|c|c|c|}
\hline Dependent variable $\rightarrow$ & \multicolumn{4}{c|}{ Tourist satisfaction } \\
\hline $\begin{array}{c}\text { Independent } \\
\text { variable } \downarrow\end{array}$ & \multicolumn{2}{|c|}{ Characteristics } & \multicolumn{2}{c|}{ Development potential } \\
\hline $\begin{array}{c}\text { Environmental } \\
\text { attitudes }\end{array}$ & Beta & $\mathrm{t}$ & Beta & $\mathrm{t}$ \\
\hline Environmental ethics & 0.211 & $2.215^{* *}$ & 0.203 & $2.162^{* *}$ \\
\hline $\begin{array}{c}\text { Environmental } \\
\text { education }\end{array}$ & 0.233 & $2.436^{* *}$ & 0.188 & $1.934^{*}$ \\
\hline
\end{tabular}




\begin{tabular}{|c|c|c|c|c|}
\hline $\begin{array}{l}\text { Environmental } \\
\text { resources }\end{array}$ & 0.224 & $2.388 * *$ & 0.236 & $2.457 * * *$ \\
\hline $\mathrm{F}$ & \multicolumn{2}{|c|}{18.324} & \multicolumn{2}{|c|}{23.517} \\
\hline Significance & \multicolumn{2}{|c|}{$0.000 * * *$} & \multicolumn{2}{|c|}{$0.000 * * *$} \\
\hline $\mathrm{R} 2$ & \multicolumn{2}{|c|}{0.168} & \multicolumn{2}{|c|}{0.195} \\
\hline Adjusted R2 & \multicolumn{2}{|c|}{0.014} & \multicolumn{2}{|c|}{0.017} \\
\hline
\end{tabular}

Note: * stands for $\mathrm{p}<0.05$, ** for $\mathrm{p}<0.01$, and $* * *$ for $\mathrm{p}<0.001$.

Data source: Self-organized in this study

\section{Correlation Analysis of tourist satisfaction and environmental behavior}

To test $\mathrm{H} 2$, the analysis result, Table 2, reveals notable effects of characteristics $\left(\mathrm{t}=2.049^{* *}\right)$ and development potential $\left(\mathrm{t}=2.377^{* *}\right)$ on persuasive action, significant effects of characteristics $\left(\mathrm{t}=2.261^{* *}\right)$ and development potential $\left(\mathrm{t}=1.833^{*}\right)$ on consumption action, remarkable effects of characteristics $\left(\mathrm{t}=2.173^{* *}\right)$ and development potential $\left(\mathrm{t}=2.415^{* *}\right)$ on ecological management, and notable effects of characteristics $\left(\mathrm{t}=2.227^{* *}\right)$ and development potential $\left(\mathrm{t}=2.566^{* * *}\right)$ on legal action that $\mathrm{H} 2$ is supported.

Table 2. Analysis of factors in tourist satisfaction and environmental behavior

\begin{tabular}{|c|c|c|c|c|c|c|c|c|}
\hline Dependent & \multicolumn{8}{|c|}{ Environmental behavior } \\
\hline $\begin{array}{l}\text { Independent } \\
\text { variable } \downarrow\end{array}$ & \multicolumn{2}{|c|}{ Persuasive action } & \multicolumn{2}{|c|}{$\begin{array}{c}\text { Consumption } \\
\text { action }\end{array}$} & \multicolumn{2}{|c|}{$\begin{array}{c}\text { Ecological } \\
\text { management }\end{array}$} & \multicolumn{2}{|c|}{ Legal action } \\
\hline $\begin{array}{l}\text { Tourist } \\
\text { satisfaction }\end{array}$ & Beta & $\mathrm{t}$ & Beta & $\mathrm{t}$ & Beta & $\mathrm{t}$ & Beta & $\mathrm{t}$ \\
\hline Characteristics & 0.192 & $2.049 * *$ & 0.218 & $2.261 * *$ & 0.206 & $2.173 * *$ & 0.211 & $2.227 * *$ \\
\hline $\begin{array}{l}\text { Development } \\
\text { potential }\end{array}$ & 0.229 & $2.377 * *$ & 0.174 & $1.833^{*}$ & 0.235 & $2.415^{* *}$ & 0.243 & $2.566 * * *$ \\
\hline $\mathrm{F}$ & \multicolumn{2}{|c|}{16.416} & \multicolumn{2}{|c|}{19.372} & \multicolumn{2}{|c|}{22.155} & \multicolumn{2}{|c|}{24.882} \\
\hline Significance & \multicolumn{2}{|c|}{$0.000 * * *$} & \multicolumn{2}{|c|}{$0.000 * * *$} & \multicolumn{2}{|c|}{$0.000 * * *$} & \multicolumn{2}{|c|}{$0.000 * * *$} \\
\hline $\mathrm{R} 2$ & \multicolumn{2}{|c|}{0.173} & \multicolumn{2}{|c|}{0.196} & \multicolumn{2}{|c|}{0.223} & \multicolumn{2}{|c|}{0.241} \\
\hline Adjusted R2 & \multicolumn{2}{|c|}{0.015} & \multicolumn{2}{|c|}{0.017} & \multicolumn{2}{|c|}{0.020} & \multicolumn{2}{|c|}{0.022} \\
\hline
\end{tabular}

Note: * stands for $\mathrm{p}<0.05$, ** for $\mathrm{p}<0.01$, and $* * *$ for $\mathrm{p}<0.001$.

Data source: Self-organized in this study

\section{Correlation Analysis of environmental attitudes and environmental behavior}

To test H3, the analysis result, Table 3, presents significant effects of environmental ethics $\left(\mathrm{t}=2.233^{* *}\right)$, environmental education $\left(\mathrm{t}=2.351^{* *}\right)$, and environmental resources $\left(\mathrm{t}=2.138^{* *}\right)$ on persuasive action, remarkable effects of environmental ethics $\left(\mathrm{t}=2.259^{* *}\right)$, environmental education $\left(\mathrm{t}=2.414^{* *}\right)$, and environmental resources $\left(\mathrm{t}=2.323^{* *}\right)$ on consumption action, notable effects of environmental ethics $\left(\mathrm{t}=1.942^{*}\right)$, environmental education $\left(\mathrm{t}=2.055^{* *}\right)$, and environmental resources $\left(\mathrm{t}=1.826^{*}\right)$ on 
ecological management, as well as significant effects of environmental ethics $\left(\mathrm{t}=2.012^{* *}\right)$, environmental education $\left(\mathrm{t}=2.436^{* *}\right)$, and environmental resources $\left(\mathrm{t}=1.868^{*}\right)$ on legal action that $\mathrm{H} 3$ is supported.

Table 3. Analysis of factor in environmental attitudes and environmental behavior

\begin{tabular}{|c|c|c|c|c|c|c|c|c|}
\hline \multirow{3}{*}{$\begin{array}{l}\text { Dependent } \\
\text { variable } \rightarrow \\
\text { Independent } \\
\text { variable } \downarrow \\
\text { Environmental } \\
\text { attitudes }\end{array}$} & \multicolumn{8}{|c|}{ Environmental behavior } \\
\hline & \multicolumn{2}{|c|}{ Persuasive action } & \multicolumn{2}{|c|}{$\begin{array}{l}\text { Consumption } \\
\text { action }\end{array}$} & \multicolumn{2}{|c|}{$\begin{array}{l}\text { Ecological } \\
\text { management }\end{array}$} & \multicolumn{2}{|c|}{ Legal action } \\
\hline & Beta & $\mathrm{t}$ & Beta & $\mathrm{t}$ & Beta & $\mathrm{t}$ & Beta & $\mathrm{t}$ \\
\hline $\begin{array}{l}\text { Environmental } \\
\text { ethics }\end{array}$ & 0.216 & $2.233^{* *}$ & 0.218 & $2.259 * *$ & 0.183 & $1.942^{*}$ & 0.192 & $2.012 * *$ \\
\hline $\begin{array}{l}\text { Environmental } \\
\text { education }\end{array}$ & 0.222 & $2.351 * *$ & 0.231 & $2.414 * *$ & 0.197 & $2.055^{* *}$ & 0.238 & $2.436 * *$ \\
\hline $\begin{array}{l}\text { Environmental } \\
\text { resources }\end{array}$ & 0.207 & $2.138^{* *}$ & 0.227 & $2.323 * *$ & 0.176 & $1.826^{*}$ & 0.171 & $1.868^{*}$ \\
\hline $\mathrm{F}$ & \multicolumn{2}{|c|}{17.514} & \multicolumn{2}{|c|}{20.628} & \multicolumn{2}{|c|}{24.512} & \multicolumn{2}{|c|}{26.441} \\
\hline Significance & \multicolumn{2}{|c|}{$0.000 * * *$} & \multicolumn{2}{|c|}{$0.000 * * *$} & \multicolumn{2}{|c|}{$0.000 * * *$} & \multicolumn{2}{|c|}{$0.000 * * *$} \\
\hline $\mathrm{R} 2$ & \multicolumn{2}{|l|}{0.151} & \multicolumn{2}{|l|}{0.168} & \multicolumn{2}{|l|}{0.194} & \multicolumn{2}{|l|}{0.218} \\
\hline Adjusted R2 & \multicolumn{2}{|l|}{0.013} & \multicolumn{2}{|l|}{0.014} & \multicolumn{2}{|l|}{0.017} & \multicolumn{2}{|l|}{0.019} \\
\hline
\end{tabular}

Note: $*$ stands for $\mathrm{p}<0.05, * *$ for $\mathrm{p}<0.01$, and $* * *$ for $\mathrm{p}<0.001$.

Data source: Self-organized in this study

\section{Conclusion}

The research results show that visitors with positive environmental attitudes towards eco-tourism could better perform correct environmental behavior. Eco-tourism is getting popular in Taiwan, and the promotion by relevant government sectors has various ecological tours be promoted in travel markets in past years. It is therefore a new trend to develop sightseeing. Nonetheless, a large quantity of population flooding in ecological conservation zones would result in pressure on the load of conservation zones. The management of conservation zones in Taiwan is still lack of the concept of visitor capacity and perfect monitoring systems that it could easily result in negative effects on conservation zones. The propaganda and education of environmental conservation and eco-tourism therefore should be reinforced to propagate the importance of ecological conservation and the idea of environment sustainable development to the mass society, reinforce the cognition of environment protection, and timely propagate ecological conservation to the mass society by holding relevant environment protection activity in order to enhance the cognition of ecological environment. In this case, it could avoid or reduce negative impacts on the environment as well as balance the development of sightseeing and ecological conservation to achieve the sustainable management of natural environmental resources. 


\section{Suggestions}

Aiming at above research results, the following suggestions are proposed in this study.

1. Relevant governmental sectors are suggested to continuously reinforce the propaganda and education of environmental conservation and eco-tourism when promoting eco-tourism. Wire, wireless TV channels and print media are so advanced nowadays that environmental education, eco-tourism content, and the spirit could be propagated through TV programs or newspaper and magazines.

2. Eco-tourism parks are suggested to continuously present the public authority to have visitors intangibly establish the different image between conservation zones and general recreation areas and to prohibit vendors randomly running in conservation zones to avoid environmental pollution. Ecological conservation zones delivering positive environmental resource conservation information could have visitors learn to respect life, the environment, and culture in the travel process and allow the eco-tourism experience extending to the re-thinking of environment feedback.

3. Relevant sectors are suggested to combine neighboring touring spots, design package tours including ecological and cultural travel, and match with local characteristic produce and food to attract visitors, when promoting eco-tourism. It could further enhance local and economic development.

4. In terms of enhancing the propaganda and education of environmental conservation and eco-tourism, schools and eco-tourism sectors could hold natural environment and ecology related interpretation summer camps to enhance students' cognition of the environment and ecology and to cultivate good environmental attitudes and behavior of the public. In this case, students around eco-tourism parks could be proceeded ecological interpretation activity to train the basic concept about ecological conservation and eco-tourism.

\section{REFERENCE}

[1] Ahmed, A., Masud, M. M., Al-Amin, A. Q., Yahaya, S. R. B., Rahman, M., Akhtar, R. (2015): Exploring factors influencing farmers' willingness to pay (WTP) for a planned adaptation programme to address climatic issues in agricultural departments. Environmental Science and Pollution Research 22: 9494-9504.

[2] Bauer, I. (2012): Australian senior adventure travellers to Peru: Maximising older tourists' travel health experience. - Travel medicine and infectious disease 10(2): 59-68.

[3] Buckley, C., Hynes, S., Mechan, S. (2012): Supply of an ecosystem service-Farmers' willingness to adopt riparian buffer zones in agricultural catchments. - Environmental Science \& Policy 24: 101-109.

[4] Chaminuka, P., Groeneveld, R. A., Selomane, A. O., van Ierland, E. C. (2012): Tourist preferences for ecotourism in rural communities adjacent to Kruger National Park: A choice experiment approach. - Tourism Management 33: 168-176.

[5] Cheung, L. T. O., Fok, L., Fang, W. (2014): Understanding geopark visitors' preferences and willingness to pay for global geopark management and conservation. - Journal of Ecotourism 13: 35-51.

[6] Chiu, Y.-T. H.,.Lee, W.-I., Chen, T.-H. (2014): Environmentally responsible behavior in ecotourism: Antecedents and implications. - Tourism Management 40: 321-329. 
[7] Damodaran, K. (2014): Willingness To Pay For Common Property Resources: A Study In Cuddalore District, Tamil Nadu. - Eduved International Journal of Interdisciplinary Research 1(7): 1-6.

[8] de Gusmão Pedrini, A., Brotto, D. S., Ghilardi-Lopes, N. P., Lopes, M. C., Ferreira, L. P. (2015): Environmental education and ecotourism concepts in Marine Protected Area of Armação de Búzios, Rio de Janeiro, Brazil: reflections for the adoption of coastal ecotourism. - Revista Brasileira de Ecoturismo 8: 59-73.

[9] Hanington, B., Martin, B. (2012): Universal methods of design: 100 ways to research complex problems, develop innovative ideas, and design effective solutions. - Rockport Publishers. 208 pp.

[10] Hsiao,Y.Y., Ou, S.G (1998): Study on the Characteristics of Ecotourism Tourists. Journal of Landscape Design and Environmental Planning 20:293-314.

[11] Husted, B. W., Russo, M. V., Meza, C. E. B., Tilleman, S. G. (2014): An exploratory study of environmental attitudes and the willingness to pay for environmental certification in Mexico. - Journal of Business Research 67: 891-899.

[12] Jung, W.J., Kim, T.H., Lee, S.Y. T. (2015): The Study on the Value of New \& Renewable Energy as a Future Alternative Energy Source in Korea. - Advanced Science and Technology Letters 86: 26-31.

[13] Kang, K.H., Stein, L., Heo, C.Y., Lee, S. (2012): Consumers' Willingness to Pay for Green Initiatives of the Hotel Industry. - International Journal of Hospitality Management 31(2): 564-572.

[14] Ke, L.(2012): The weakness and innovation of China eco-tourism. - Physics Procedia 25: 953-957.

[15] Lemes, M. T., Nunes, J. R., Nunes, P. A., Oliveira, S. S. (2014): Contribution of Ecotourism and Environmental Education at a resort located in the city of Nobres (MT, Brazil). - Revista Brasileira de Ecoturismo 7(1): 151-167.

[16] Lo, A. Y., Jim, C. Y. (2015): Protest response and willingness to pay for culturally significant urban trees: Implications for Contingent Valuation Method. - Ecological Economics 114: 58-66.

[17] Lu, W., Stepchenkova, S. (2012): Ecotourism experiences reported online: Classification of satisfaction attributes. - Tourism Management 33(3): 702-712.

[18] Ly, T. P., Bauer, T. (2014): Ecotourism in mainland Southeast Asia: Theory and practice. - Tourism, Leisure and Global Change 1: 20.

[19] Maulidya, F., Mudzakir, A., Sanjaya, Y. (2014): Case Study the Environmental Literacy of Fast Learner Middle School Students in Indonesia. - Environmental Education 3: 193-197.

[20] Nunkoo, R., Ramkissoon, H. (2011): Residents' satisfaction with community attributes and support for tourism. - Journal of hospitality and tourism research 35(2): 171-190.

[21] Ramdas, M., Mohamed, B. (2014): Impacts of Tourism on Environmental Attributes, Environmental Literacy and Willingness to Pay: A Conceptual and Theoretical Review. Procedia - Social and Behavioral Sciences 144: 378-391.

[22] Reimer, J. K., Walter, P. (2013): How do you know it when you see it? Community-based ecotourism in the Cardamom Mountains of southwestern Cambodia. Tourism Management 34: 122-132.

[23] Samdin, Z., Aziz, Y. A., Radam, A., Yacob, M. R. (2013): Sustainability Of Ecotourism Resources At Taman Negara National Park: Contingent Valuation Method. - International Journal of Business and Society 14: 235-244.

[24] Satyanarayana, B., Bhanderi, P., Debry, M., Maniatis, D., Foré, F., Badgie, D., Jammeh, K., Vanwing, T., Farcy, C., Koedam, N. (2012): A socio-ecological assessment aiming at improved forest resource management and sustainable ecotourism development in the 
mangroves of Tanbi Wetland National Park, The Gambia, West Africa. - Ambio 41: 513-526.

[25] Senyolo, G. M., Wale, E., Ortmann, G. F. (2014): Consumers' Willingness-To-Pay for Underutilized Vegetable Crops: The Case of African Leafy Vegetables in South Africa. J Hum Ecol 47(3): 219-227.

[26] Shen, H.L. (2013): Study on Non-use Values of Ecotourism Resources at Taroko National Park, Taiwan. - Journal of Anhui Agricultural Sciences 5: 80.

[27] Shrode, F. (2012): Mobile apps for nature field guides. - Reference Reviews 26(7): 4-6.

[28] Teksoz, G., Sahin, E., Tekkaya-Oztekin, C. (2012): Modeling Environmental Literacy of University Students. - Journal of Science Education and Technology 21: 157-166.

[29] Wu, B. (2012): The Promise and Challenge of Ecotourism. - Social Space 92: 106-109.

[30] Zhou, Y., Buesching, C. D., Newman, C., Kaneko, Y., Xie, Z., Macdonald, D. W. (2013): Balancing the benefits of ecotourism and development: The effects of visitor trail-use on mammals in a Protected Area in rapidly developing China. - Biological Conservation 165: $18-24$.

[31] Zsóka, Á., Szerényi, Zs. M., Széchy, A., Kocsis, T. (2013): Greening due to environmental education? Environmental knowledge, attitudes, consumer behavior and everyday pro-environmental activities of Hungarian high school and university students. Journal of Cleaner Production 48: 126-138. 